\title{
A YOUNG PATIENT IN KOREA WITH KRUKENBERG TUMORS ARISING FROM BREAST CANCER: A CASE REPORT
}

\author{
Ha Yan Kwon, MD, Eun Ji Nam, MD, Sang Wun Kim, MD, Young Tae Kim, MD, PhD \\ Division of Gynecologic Oncology, Department of Obstetrics and Gynecology, Yonsei University College of Medicine, Seoul, Korea
}

\begin{abstract}
Metastasis of breast cancer to lung, bone and liver is common, but metastasis to ovaries is rare in Korea. A 31-year-old woman diagnosed with breast cancer was referred to our department due to a newly detected adnexal mass via abdomen sonography during regular check-up. Imaging studies revealed solid mass on left ovary and enlarged lymph nodes. She underwent a laparotomy including hysterectomy, bilateral salpingo-oophorectomy, lymphadenectomy, with a suspected impression of primary ovarian neoplasms or Krukenberg tumors. Pathologic findings revealed metastatic adenocarcinoma from breast cancer involving left ovary and paraaortic lymph nodes. To our knowledge, this is the youngest Korean patient with Krukenberg tumors from the breast. In Korea, since the average age affected by breast cancer is younger than in the West, and the incidence and the mortality of breast cancer has increased, possible ovarian metastasis should be kept in mind when Korean patient with breast cancer visits for follow-up.
\end{abstract}

Keywords: Krukenberg tumor; Breast neoplasm; Young female

Krukenberg tumors, which refer to metastatic ovarian tumors originating from various sites, account for about $0.7-6.7 \%$ of ovarian tumors and $10-30 \%$ of malignant ovarian tumors $[1,2]$. The primary origin sites are usually the gastrointestinal (GI) tract, including the stomach and colon, the gall bladder/biliary tract, breast and others. In both Asia and the West, most metastatic ovarian tumors originate from the GI tract; others origin show different proportions because of the incidence and commonly affected ages of primary cancer.

Ovarian metastasis from breast cancer is not frequent in Asia and breast cancer in Asian women occurs at a younger age between 30 and 40 with locally-advanced stage III disease, unlike the West where women typically present after age 50 with early stage disease. Here we present the case of the youngest patient in Korea with Krukenberg tumors arising from breast cancer.

\section{Case Report}

A 31-year-old married female (gravida 2, para 2) was diagnosed with left breast cancer involving axillary lymph nodes metastasis
(T3N2M0, stage IIIa) in September 2007. After neoadjuvant chemotherapy and radiotherapy, she underwent a left modified radical mastectomy with lymph nodes dissection. The final pathology revealed an invasive ductal carcinoma metastasized in 13 of 16 lymph nodes, and the immunohistochemical results were positive for estrogen receptors (ER), progesterone receptors (PR) and human epidermal growth factor receptor 2 protein (Her2/neu). There were no BRCA 1 and BRCA 2 mutations. She was given further

Received: 2011. 4.11. Revised: 2011. 7.26. Accepted: 2011. 8. 4. Corresponding author: Young Tae Kim, MD, PhD Division of Gynecologic Oncology, Department of Obstetrics and Gynecology, Yonsei University College of Medicine, C.P.O. Box 8044, Seoul 120-752, Korea

Tel: +82-2-2228-2230 Fax: +82-2-313-8357

E-mail: ytkchoi@yuhs.ac

This is an Open Access article distributed under the terms of the Creative Commons Attribution Non-Commercial License (http://creativecommons.org/licenses/ by-nc/3.0/) which permits unrestricted non-commercial use, distribution, and reproduction in any medium, provided the original work is properly cited.

Copyright (๑) 2011. Korean Society of Obstetrics and Gynecology 


\section{KOREAN JOURNAL OF OBSTETRICS \& GYNECOLOGY}

KJOG Vol. 54, No. 10, 2011

chemotherapy with adriamycin and docetaxel, and underwent postoperative radiotherapy and hormone therapy. She got a checkup every six months regularly. In June 2009, after two years under the diagnosis of breast cancer, a huge mass with a solid component on the left adnexa was found via abdomen ultrasonography. The magnetic resonance imaging revealed about $10 \mathrm{~cm}$ sized solid mass on left ovary and enlarged paraaortic lymph nodes (Fig. 1). The positron emission tomography-computed tomography showed a huge mass with intense fludeoxyglucose uptake in the left adnexa and the paraaortic lymph nodes were enlarged with mild uptake (Fig. 2). Plasma cancer-related antigen (CA) 15-3 level was gradually elevated (10.3 to $34.4 \mathrm{U} / \mathrm{mL}$ among 6 months) and

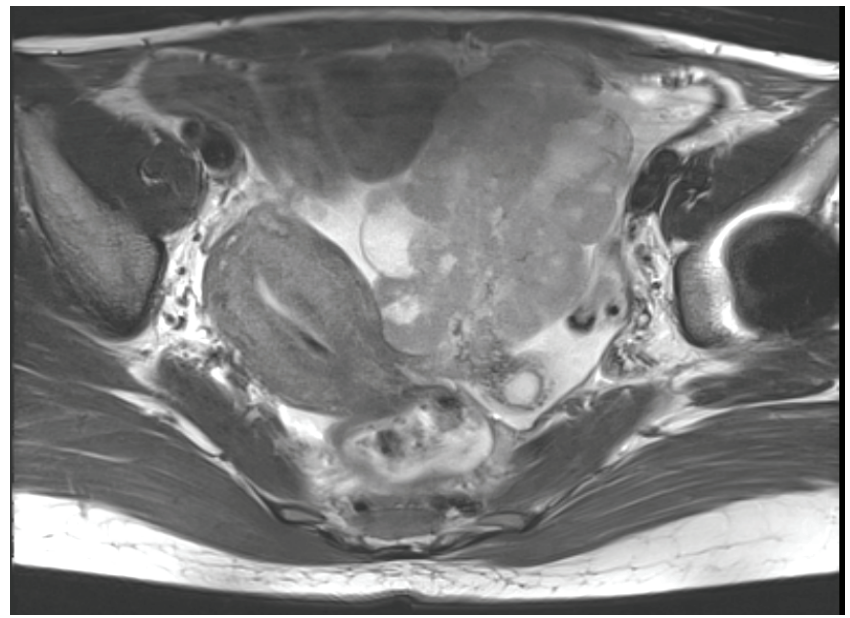

Fig. 1. The magnetic resonance imaging showed a solid mass lesion about $10 \mathrm{~cm}$ in size with peripheral cystic portions on left ovary.

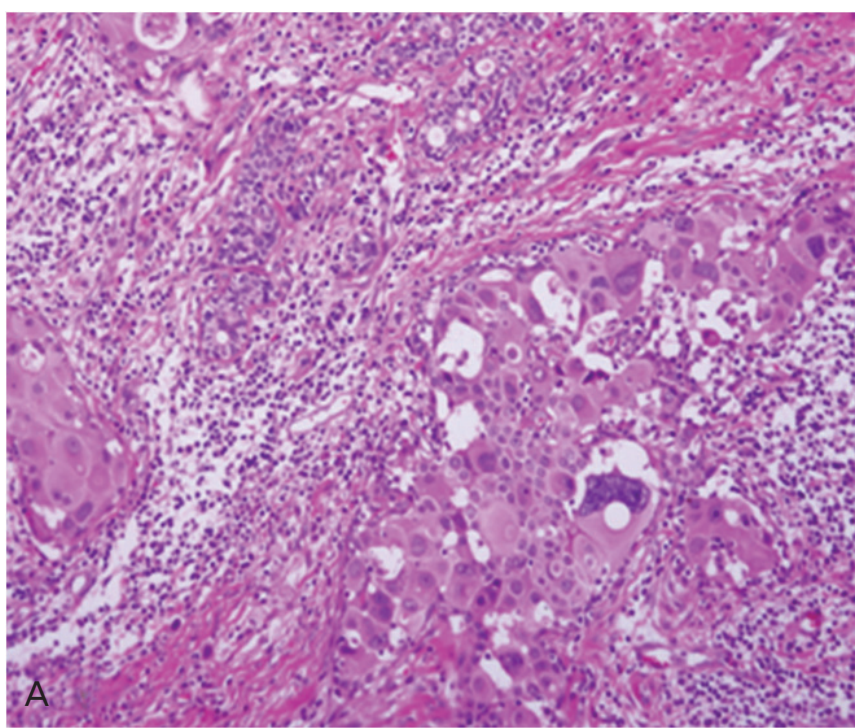

CA-125 level was elevated $(50.9 \mathrm{U} / \mathrm{mL})$ in June 2009. Esophagogastroduodenoscopy and colonoscopy revealed no significant abnormal lesions. After considering all the factors, she underwent a laparotomy including total abdominal hysterectomy, bilateral salpingo-oophorectomy, total omentectomy, bilateral pelvic lymph node dissection and paraaortic lymph node dissection assuming primary ovarian cancer or Krukenberg tumors. Pathology, including histologic findings, revealed metastatic adenocarcinoma from breast cancer involving the left ovary and paraaortic lymph node (Fig. 3). Immunohistochemical staining was similar in breast sam-
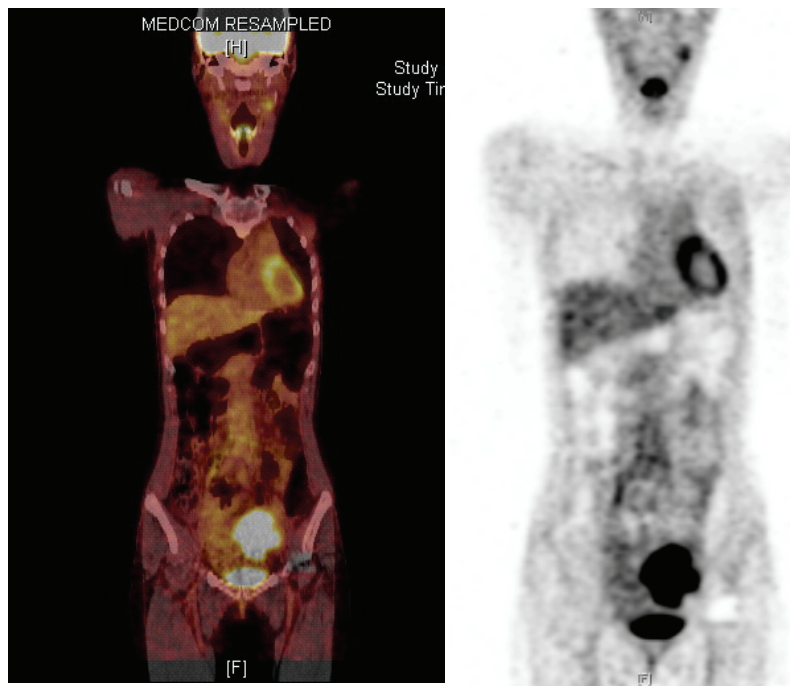

Fig. 2. The positron emission tomography-computed tomography showed cystic type, $10 \mathrm{~cm}$ in sized, intense fludeoxyglucose uptake on the left adnexa and there was mild uptake of paraaortic lymph node metastasis.

Fig. 3. (A) Breast cancer: invasive ductal carcinoma. (B) Left ovary: metastatic $(H \& E, \times 100)$.

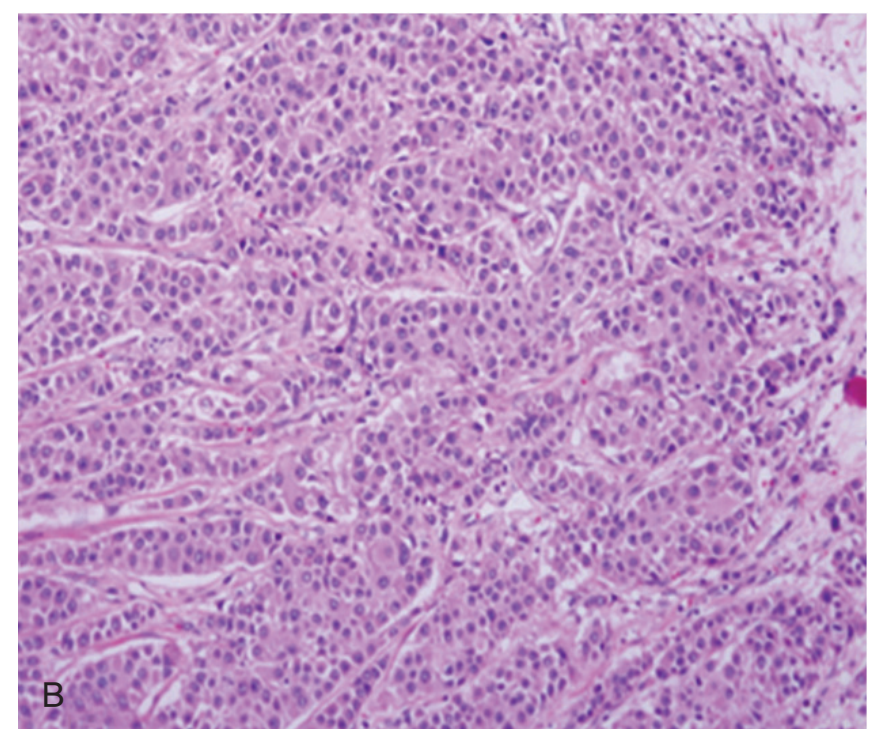




\section{KOREAN JOURNAL OF OBSTETRICS \& GYNECOLOGY}

Ha Yan Kwon, et al. A young Korean patient with Krukenberg tumors from breast cancer

ples: positive for ER, PR, Her2/neu and negative c-kit. There were no metastatic lesions including in the right ovary, pelvic lymph node or other genital organs. She had no postoperative complications. After 16 days of operation, she received chemotherapy with trastuzumab-paclitaxel. No tumor recurrence was shown in the abdominal computed tomography that was done as a follow-up image in December 2010.

\section{Discussion}

Krukenberg tumors are metastatic ovarian tumors from various sites. The primary cancer causing Krukenberg tumors are usually $\mathrm{Gl}$ cancer from either gastric or colorectal cancer, and others are breast, gall bladder, pancreas, appendix and unknown. Throughout the world, GI cancers are the most common primary cancer. But the distribution of affected primary origins differs between the Asia and the West. de Waal et al. [3] reported that the GI tract was the most common primary site (39\%), followed by the breast (28\%) and gynecologic organs (26\%). In other study [4], 76\% of patients had Gl primary cancer, followed by the breast $(7 \%)$. However, in Korea, the primary origin was the stomach (46.2\%), the colon (38.6\%), the appendix (6.3\%), and the breast (1.9\%) [5]. This can be explained by difference in primary cancer incidences. In Korea, the incidence of gastric cancer is relatively higher than in the west, but that of breast cancer is rather low. Metastasis of gastric cancer to the ovaries is therefore common, but that of breast cancer is rare in Korea [6].

The patients' age range was 40-50 years [2,4] and almost patients were premenopausal in Krukenberg tumors. de Waal et al. [3] reported the median age for metastatic ovarian tumors to be 49.5 (range, 24-79) while the mean age for primary ovarian cancer was 55 (range, 11-92). Kiyokawa et al. [4] reported on patients ranging in age from 13 to 84 years, with an average age of 45 in 120 cases. It is known that mean age for Krukenberg tumors is 10 years younger than that of primary ovarian cancer. But, this is explained by the predominance of gastric cancer as a primary sites of originating for Krukenberg tumors, which is common in younger female [4].

In our hospital, between March 2003 and January 2011, one hundred fifty-eight women were diagnosed Krukengerg tumors with pathologically or image studies. The primary sites were stomach (72.2\%), colon (20.9\%), breast (2.5\%), appendix (1.3\%), hepatobiliary tract $(1.3 \%)$, pancreas $(0.6 \%)$, small bowel $(0.6 \%)$, and kidney $(0.6 \%)$. The median age of all the patients at the time of discovery of the metastasis was 45.2 years (range, 21-73 years). Even if a small number of patients, our data showed that Krukenberg tumors originating breast cancer was rare $(2.5 \%)$, and primary sites of younger patients were almost stomach, as other studies. Ovarian metastasis from breast cancer are reported at autopsy in $2.6 \%$ to $23.4 \%$ in large series, and at oophorectomy for metastatic disease in $25 \%$ of patients with breast cancer [7]. Tserkezoglou et al. [8], reported the median age of nine patients who had ovarian metastasis from breast cancer to be 54 (rang, 39-73), while others have reported a median age of about 46-50 [3,4]. Metastatic tumors from breast cancer are characterize by the relatively small size of the lesion [9]. In pathologic diagnosis, ductal cancer is considerably more common in breast cancer, but lobular carcinoma spread to the ovary more frequently than ductal carcinoma [6]. The route of metastasis to ovary from breast were not identified definitely, but nodular or infiltrating involvement were considered. Carcinoembryonic antigen and CA 15-3 can be followed over time for metastatic breast cancer with CA-125. However, the tests are not very sensitive, it can be used with other image studies.

Ovarian metastasis from breast cancer may appear many years after initial diagnosis, because breast cancer is among the more slow-growing solid tumors. The median time relapse between primary breast cancer diagnosis and diagnosis of ovarian metastasis was five years (range, $0-20$ years) in studies by Bigorie et al. [10]. Tserkezoglou et al. [8] reported that $56 \%$ of patients were diagnosed with metastasis to the ovaries five years after breast cancer diagnosis. There are no clear guidelines about metastatic breast cancer to the ovaries, and it is difficult to find until a patient complains of abdominal pain or distention. Diagnosis and cytoreductive surgery have probable survival benefits in recent studies [1], and it is important to detect and treat ovarian metastasis promptly. Especially breast cancer in Asian women occurs at a younger age and is usually presented and diagnosed at a later stage of development, gynecologic evaluation for follow-up after breast cancer and screening for distant metastasis should have come to the fore in young Asian patients.

To the best of our knowledge, this is the youngest patient of Krukenberg tumors from breast cancer. This report may help improve the current understanding of metastatic ovarian cancer originating breast cancer.

\section{References}

1. Jiang R, Tang J, Cheng X, Zang RY. Surgical treatment for pa- 


\section{KOREAN JOURNAL OF OBSTETRICS \& GYNECOLOGY}

KJOG Vol. 54, No. 10, 2011

tients with different origins of Krukenberg tumors: outcomes and prognostic factors. Eur I Surg Oncol 2009;35:92-7.

2. Yada-Hashimoto $N$, Yamamoto T, Kamiura S, Seino H, Ohira $H$, Sawai $K$, et al. Metastatic ovarian tumors: a review of 64 cases. Gynecol Oncol 2003;89:314-7.

3. de Waal YR, Thomas CM, Oei AL, Sweep FC, Massuger LF. Secondary ovarian malignancies: frequency, origin, and characteristics. Int J Gynecol Cancer 2009;19:1160-5.

4. Kiyokawa T, Young RH, Scully RE. Krukenberg tumors of the ovary: a clinicopathologic analysis of 120 cases with emphasis on their variable pathologic manifestations. Am J Surg Pathol 2006;30:277-99.

5. Kim WY, Kim TJ, Kim SE, Lee JW, Lee JH, Kim BG, et al. The role of cytoreductive surgery for non-genital tract metastatic tumors to the ovaries. Eur J Obstet Gynecol Reprod Biol 2010;149:97-101.

6. Young RH. From Krukenberg to today: the ever present prob- lems posed by metastatic tumors in the ovary. Part II. Adv Anat Pathol 2007;14:149-77.

7. Hann LE, Lui DM, Shi W, Bach AM, Selland DL, Castiel M. Adnexal masses in women with breast cancer: US findings with clinical and histopathologic correlation. Radiology 2000;216:242-7.

8. Tserkezoglou A, Kontou S, Hadjieleftheriou G, Apostolikas N, Vassilomanolakis $\mathrm{M}$, Sikiotis $\mathrm{K}$, et al. Primary and metastatic ovarian cancer in patients with prior breast carcinoma. Preoperative markers and treatment results. Anticancer Res 2006;26:2339-44.

9. Koyama T, Mikami Y, Saga T, Tamai K, Togashi K. Secondary ovarian tumors: spectrum of $\mathrm{CT}$ and MR features with pathologic correlation. Abdom Imaging 2007;32:784-95.

10. Bigorie V, Morice P, Duvillard P, Antoine M, Cortez A, Flejou $J F$, et al. Ovarian metastases from breast cancer: report of 29 cases. Cancer 2010;116:799-804.

\section{유방암이 진단된 젊은 한국 여성에서 발견한 크루켄버그종양 1 예}

\section{연세대학교 의과대학 산부인과학교실}

권하얀, 남은지, 김상운, 김영태

크루켄버그종양은 난소에 전이되는 이차성 난소암으로 전체 난소종양 중 약 0.7-6.7\%를 차지하며 주로 40-50대의 여성에서 호발한다. 원발 부위로는 위, 직장, 유방, 췌담관 등이 있으며 주로 위와 직장에서 전이 된다. 크루켄버그종양은 다른 기관으로의 전이를 의미하기 때 문에 예후가 안 좋다고 알려져 있지만 종양감축술을 시행할 경우 생존율을 올리는데 도움이 되기 때문에 조기 발견은 환자의 삶의 질과 생존율을 높이는 데 중요하다. 한국과 서양은 원발 부위의 비율에 차이가 있는데 한국은 서양에 비해 유방암에서 전이된 크루켄버그종양 이 드물다. 또한 크루켄버그종양은 난소암에 비해 10년 정도 호발 연령이 어리다. 따라서 유방암을 진단 받은 젊은 한국 여성이 난소에 종 양이 있을 경우 크루켄버그종양일 가능성을 염두해 두고 검사와 추적관찰을 진행하는 것이 전이를 조기 발견하고 생존율을 높이는 데 중 요하다. 본 병원에서는 원발성 유방암 진단 후 난소에 전이된 크루켄버그종양을 진단 받은 31세의 젊은 환자의 증례를 통하여 이를 고찰 해보고자 한다.

중심단어: 크루켄버그종양, 유방암, 난소전이, 젊은 한국 여성 